\title{
Application of Inorganic Fertilizers and The Seedling Number on Growth and Production of Rice (Oryza
} sativa L.)

\author{
Sudirman \\ Sekolah Tinggi Penyuluhan \\ Pertanian Gowa \\ Gowa, Indonesia
}

\author{
Ramli \\ Sekolah Tinggi Penyuluhan \\ Pertanian Gowa \\ Gowa, Indonesia
}

\author{
Buchaerah \\ Sekolah Tinggi Penyuluhan \\ Pertanian Gowa \\ Gowa, Indonesia
}

\author{
Rachmat \\ Sekolah Tinggi Penyuluhan \\ Pertanian Gowa \\ Gowa, Indonesia
}

\begin{abstract}
The investigation was carried out to determine effect of various doses of inorganic fertilizers and the paddy seedlings number on growth and production (Oryza sativa L.) Three kinds of fertilizer doses are 150-60-67.5 kg/ha, 250-75-75 $\mathrm{kg} / \mathrm{ha}$ and $350-90-82.5 \mathrm{~kg} / \mathrm{ha}$ and the number of seeds per planting hole is 20,25 and 30. This is the experimental research with using split plot design and nine combination treatment. The main plot is the inorganic fertilizers with three level doses, and the sub-plot is some seeds per planting hole. The result shows that the best dose of inorganic fertilizer is $350-90-82.5 \mathrm{~kg} / \mathrm{ha}$ which rice growth result are plant height $108,95 \mathrm{~cm}, 35,30$ productive panicles and length of panicles is $27.03 \mathrm{~cm}$. Rice production is 7.69 ton/ha. The best number of the seedling is 25 seeds per planting hole with growth result are plant height 109.52 $\mathrm{cm}, 35,48$ productive panicles and length of panicles is $26.65 \mathrm{~cm}$. Rice production is 7.72 ton/ha.
\end{abstract}

Keywords-fertilizer; seedling; rice

\section{INTRODUCTION}

The Indonesia Central Bureau of Statistics had released that the number of population of Indonesia is about 254.9 million in 2015. By the based on the prediction for the future, the number of population will increase. It means the demand for rice as a staple food source will also increase. The fact of rice production in Indonesia in the last five years show declining of rice production and increasing costs of production.

Rice production is focused on two effort that expansion of planting areas and intensification with increasing of yield without adverse environmental impact and cultivation in more land [1]. Sustainable intensification in agriculture also supported by the use of fertilizers. However, the excessive use of chemicals in agriculture causes water pollution and human health hazards. Therefore, the application system of rice intensification technology would be essential for the sustainable production of rice. [2].

Inorganic and organic fertilizations have an impact on the ecological condition regard to bacterial and fungal communities.[3]. Furthermore, rice straw compost is the source of fertilizer in the land. The yields in the organic fertilizer (OF) plot, in which $60 \%$ of the nitrogen was derived from, were lower than those in the inorganic fertilizer (IF) plot for the first ten years. [4].

In Indonesia, the rice varieties influence the growth of paddy. The difference between the local varieties and superior varieties is indicated on the results of production. Superior has a big production, short plants, upright leaves, a lot of productive seed, the plants resistant to fall and the age of the plants short. A seeding rate of rice planting influences the yield production and cost. The previous research showed that optimum seeding rate is $128 \mathrm{~kg} / \mathrm{ha}$ for a higher yield and cost reduction [5].

Based on the explanation, this research carried out to determine the effect of various doses of inorganic fertilizers and the number of seedlings on growth and production of rice (Oryza Sativa L.).

\section{METHOD}

This research is conducted at Gowa South Sulawesi was held in March until October 2016. The seed of the variety was Inpari 33 and inorganic N fertilizer (urea), P (SP36) and K $(\mathrm{KCl})$. The research was using the Split-Plot Design which consists of two factors. The main plot was the inorganic fertilizers with dose of $150-60-67.5 \mathrm{~kg} / \mathrm{ha}(\mathrm{P} 1)$, the dose is $250-75-75 \mathrm{~kg} / \mathrm{ha}(\mathrm{P} 2)$ and a dose of $350-90-82.5 \mathrm{~kg} / \mathrm{ha}(\mathrm{P} 3)$, and the subplot was 20 seeds/planting hole (B1), 25 seeds/planting hole (B2) and 30 seeds/planting hole (B3). In addition, the step of research was tillage, seedbed preparation, planting and seeding, the stitching, fertilization, pest control and harvesting plant diseases. The variable of the investigation is height $(\mathrm{cm})$, the number of productive panicles, the length of panicles, and rice production per ha. 


\section{RESULT AND DisCUSS}

\section{A. The height of plants}

Test results of the height of plants show on Duncan table (Table 1) and indicate that fertilizer treatment $\mathrm{P} 1$ gives the highest plant $(190.62 \mathrm{~cm})$. Furthermore, the number of B3 resulted in the highest plant $(109.52 \mathrm{~cm})$ and no real different with other treatments.

TABle I. Average Height of Plants (CM) AT THE AgE OF $2-8$ WEEKS ON VARIOUS TYPES OF INORGANIC FERTILIZERS AND THE NUMBER OF SEEDS

\begin{tabular}{|c|c|c|c|c|}
\hline Treatment & \multicolumn{4}{|c|}{ Weeks } \\
\hline Fertilizer (kg/ha) & 2 & 4 & 6 & 8 \\
\hline P1 (150-60-67,5) & 61,85 & 84,52 & 99,59 & 108,95 \\
\hline P2 (250-75-75) & 60,56 & 83,70 & 99,85 & 108,74 \\
\hline P3 (350-90-82,5) & 60,56 & 83,78 & 98,96 & 108,78 \\
\hline \multicolumn{5}{|c|}{ Number of Seeds/planting hole } \\
\hline B1 (20) & 59,22 & 82,63 & 98,44 & 107,28 \\
\hline B2 (25) & 59,11 & 83,07 & 98,96 & 109,11 \\
\hline B3 (30) & 64,63 & 86,30 & 101,00 & 109,52 \\
\hline
\end{tabular}

\section{B. The number of productive panicles}

The results of a number of productive panicles in Duncan table (Table 2) shows that the fertilizer treatment $\mathrm{P} 1$ gives the highest results of a number of panicles productive 35.30 stems. The growth from seeds B1 led to the best of rice growth.

TABLE II. AVERAGE Number of PANICLES OF PRODUCTIVE ON TREATMENT OF INORGANIC FERTILIZERS AND THE NUMBER OF SEEDS

\begin{tabular}{|l|l|l|l|l|}
\hline \multicolumn{1}{|c|}{ Treatment } & \multicolumn{1}{|c|}{ B1 } & B2 & B3 & \multicolumn{1}{c|}{ Average } \\
\hline P1 & 33,78 & 39,22 & 32,89 & 35,30 \\
\hline P2 & 34,22 & 35,22 & 33,44 & 34,29 \\
\hline P3 & 35,33 & 32,00 & 36,33 & 34,55 \\
\hline Rerata & 34,44 & 35,48 & 34,22 & \\
\hline
\end{tabular}

\section{Units}

Panicles is a significant component yield of rice, its length of the rice panicle determines the number of grains it can hold, and consequently rice yield. The panicle length was calculated as the sum of the distances between each adjacent path point.

The Duncan table represented on the length of panicles observations shows that fertilizer treatment P1 gives the highest results with the length of panicles is $27.03 \mathrm{~cm}$. A number of seed treatment B2 gives the highest results $(26.65$ $\mathrm{cm})$ and no real different with other treatments.
TABLE III. THE AVERAGE LENGTH OF THE PANICLES (CM) AT THE END OF THE EXPERIMENTAL TREATMENT OF INORGANIC FERTILIZERS AND THE NUMBER OF SEEDS

\begin{tabular}{|l|l|l|l|l|}
\hline \multicolumn{1}{|c|}{ Treatment } & \multicolumn{1}{c|}{ B1 } & \multicolumn{1}{c|}{ B2 } & \multicolumn{1}{c|}{ B3 } & \multicolumn{1}{c|}{ Average } \\
\hline P1 & 26,03 & 26,06 & 25,81 & 25,97 \\
\hline P2 & 26,37 & 25,42 & 25,77 & 25,85 \\
\hline P3 & 25,74 & 28,46 & 26,90 & 27,03 \\
\hline Average & 26,05 & 26,65 & 26,16 & \\
\hline
\end{tabular}

\section{Production}

The observation of production shows in table 4 . The best fertilizer treatment is P3 with average production is 7.69 ton ha-1, while the optimum number of seeds with the highest average production is $\mathrm{B} 2$ with 7.72 ton ha-1 and no real different with other treatments

TABLE IV. THE AVERAGE PRODUCTION (TONS) HA-1 AT THE END OF THE EXPERIMENT THE VARIOUS INORGANIC FERTILIZERS AND THE NUMBER OF SEEDS

\begin{tabular}{|l|l|l|l|l|}
\hline \multicolumn{1}{|c|}{ Treatment } & \multicolumn{1}{|c|}{ B1 } & \multicolumn{1}{c|}{ B2 } & \multicolumn{1}{c|}{ B3 } & \multicolumn{1}{c|}{ Average } \\
\hline P1 & 7,26 & 8,26 & 6,47 & 7,33 \\
\hline P2 & 7,71 & 7,08 & 7,21 & 7,33 \\
\hline P3 & 6,99 & 7,82 & 8,26 & 7,69 \\
\hline Average & 7,32 & 7,72 & 7,31 & \\
\hline
\end{tabular}

The higher of rice growth was the result of $\mathrm{P} 1$ treatment or dose $150-60-67,5 \mathrm{~kg} / \mathrm{ha}$ at the age of 8 weeks after plant. It caused by the presence of nutrient elements in soil available which used for the development of the plant. The quantity of nutrient resulted in yield level 7,33 ton/ha or $8,3 \mathrm{~kg} \mathrm{P}$ to produce one ton of grain yield. This value is greater than the results of previous research. The experiments at 11 location in Asia with a broad range of nutrient input treatments and yield levels were used to quantify crop of rice (Oryza Sativa 1.) The $\mathrm{P}$ balance in intensive irrigated rice systems. Uptake of $1.8-4.2 \mathrm{~kg} \mathrm{P}$ was required to produce one ton of grain yield. [6].

The height of plants with 30 seeds provide the highest results $(109.52 \mathrm{~cm})$ than the other treatments. This shows that the more seeds result in many opportunities for the new little plantlets formed and the plant can grow well. The number of panicle productive use of 25 seeds provide the highest grades (35.48 stems) compared with other treatments. By planting 25 seeds and the granting of organic fertilizer and inorganic could potentially generate higher productive saplings. The effects of stress associated with the production of the materials dry low during periods of flood and stress during the period of withdrawal the following stress. About the efficiency of irrigation water use, it increases under two, and by the first treatment of at least $101 \%$ to a maximum of $110 \%$ [7]. The growth of the plant with the use of the old seeds with the addition of organic fertilizer and inorganic gives a high production. 


\section{CONCLUSION}

The result shows that the best dose of inorganic fertilizer is $350-90-82.5 \mathrm{~kg} / \mathrm{ha}$ which rice growth result are plant height $108,95 \mathrm{~cm}, 35,30$ productive panicles and length of panicles is $27.03 \mathrm{~cm}$. Rice production is $7.69 \mathrm{ton} / \mathrm{ha}$. The best number of the seedling is 25 seeds per planting hole with growth result are plant height $109.52 \mathrm{~cm}, 35,48$ productive panicles and length of panicles is $26.65 \mathrm{~cm}$. Rice production is $7.72 \mathrm{ton} / \mathrm{ha}$.

\section{REFERENCES}

[1] T. J. Krupnik, S. Santos Valle, A. McDonald, S. Justice, I. Hossain, and M. K. Gathala, 'Made in Bangladesh: Scaleappropriate machinery for agricultural resource conservation', 2013.

[2] P. R. Chaudhari et al., 'Growth and yield attributes of rice (oryza sativa 1.) As influenced to age of seedlings and fertilizer management', The Ecoscan, vol. 9, no. 1\&2, pp. $471-473,2015$.

[3] J. Wang et al., 'Impacts of inorganic and organic fertilization treatments on bacterial and fungal communities in a paddy soil', Appl. Soil Ecol., vol. 112, pp. 42-50, 2017.

[4] M. Suzuki, K. Kamekawa, S. Sekiya, and H. Shiga, 'Effect of continuous application of organic or inorganic fertilizer for sixty years on soil fertility and rice yield in paddy field.', in Transactions 14th International Congress of Soil Science, Kyoto, Japan, August 1990, Volume IV, 1990, pp. 14-19.

[5] A. Muazu, A. Yahya, W. I. W. Ishak, and S. KhairunnizaBejo, 'Yield prediction modeling using data envelopment analysis methodology for direct seeding, wetland paddy cultivation', Agric. Agric. Sci. Procedia, vol. 2, pp. 181$190,2014$.

[6] A. Dobermann, K. G. Cassman, P. C. Sta. Cruz, M. A. A. Adviento, and M. F. Pampolino, 'Fertilizer inputs, nutrient balance and soil nutrient supplying power in intensive, irrigated rice system. III. Phosphorus', Nutr. Cycl. Agroecosystems, vol. 46, no. 2, pp. 111-125, 1996.

[7] G.-C. Shao, S. Deng, N. Liu, S.-E. Yu, M.-H. Wang, and D.-L. She, 'Effects of controlled irrigation and drainage on growth, grain yield and water use in paddy rice', Eur. J. Agron., vol. 53, pp. 1-9, 2014. 